\title{
Antileucoprotease in the developing fetal lung
}

\author{
L N A WILLEMS, J A KRAMPS, P K JEFFERY, J H DIJKMAN \\ From the Department of Pulmonology, University Hospital Leiden, The Netherlands, and the Department of \\ Lung Pathology, Cardiothoracic Institute, Brompton Hospital, London
}

\begin{abstract}
The distribution of antileucoprotease in the lungs of 25 fetuses of 9-40 weeks' gestation was studied with monoclonal antibodies and an indirect immunoperoxidase technique. $\overrightarrow{0}$ Antileucoprotease was detected from 16 weeks in submucosal glands and collecting ducts in the trachea and main and lobar bronchi: it was also found in the surface epithelium of the trachea at $20 \stackrel{\infty}{\perp}$ weeks, in main and lobar bronchi at 20 weeks, and in smaller bronchi at 20-25 weeks. Non-ciliated $\frac{\mathrm{O}}{5}$ cells containing antileucoprotease were observed in the bronchiolar epithelium at 36 and 40 weeks. $\overrightarrow{0}$ The results of this study indicate that antileucoprotease is available from birth. It may therefore form part of the first line of defence of the lung.
\end{abstract}

\section{Introduction}

The elastase inhibitor antileucoprotease has been localised in the adult human lung in serous cells of bronchial submucosal glands, in bronchial nonciliated epithelial cells, and in bronchiolar Clara and goblet cells, and in association with elastic fibres of alveolar septa and airway and vessel walls. ${ }^{1-5}$ In addition, we have recently shown that the amount of antileucoprotease in distal airways is related to the degree of bronchiolar inflammation and to the degree of loss of alveolar attachment to membranous bronchioles. ${ }^{6}$ The presence of this substance in the human adult lung is now well documented, and there is increasing evidence that it has a role in the defence of the lung against proteolytic enzymes.

The distribution of antileucoprotease in the fetal lung was investigated to seek support for the idea that it forms part of the first line of defence of the lung from birth, and also to provide further data on the differentiation of Clara cells in man.

\section{Methods}

Twenty five lung specimens were obtained, after informed consent had been obtained, from medically aborted fetuses, from stillborn and premature infants having necropsies, and from one mature infant dying within one day of birth. The lung specimens were

Address for reprint requests: Dr L N A Willems, Department of Pulmonology, C3-P, University Hospital Leiden, 2333 AA Leiden, The Netherlands.

Accepted 27 July 1988 immersed in Bouin's fixative for two hours, sliced before further fixation for four hours, and then $\square$ transferred to $100 \%$ ethanol for transport or storage. Tissue blocks were embedded in paraplast, and $4 \mu \mathrm{m}$ sections were cut and stained by a two step indirect immunoperoxidase method for antileucoprotease, $\stackrel{\circ}{\mathbb{Q}}$

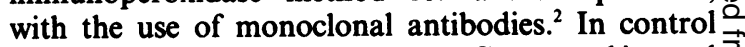
experiments non-immune mouse IgG was used instead of monoclonal antibody.

The gestational age of the lung specimens, as calculated from the last menstrual period, and their state of preservation are shown in table 1 . The surface epithelium in four of the third trimester specimens was autolysed and unsuitable for microscopic examination.

Table 1 Gestational ages and state of preservation of the 25 을 fetal lung specimens

\begin{tabular}{|c|c|c|c|}
\hline $\begin{array}{l}\text { Gestational } \\
\text { age (weeks) }\end{array}$ & $\begin{array}{l}\text { No of } \\
\text { specimens }\end{array}$ & $\begin{array}{l}\text { Tissue } \\
\text { preservation }\end{array}$ & స్ \\
\hline $\begin{array}{r}9 \\
14 \\
15 \\
16 \\
17 \\
20 \\
23 \\
25 \\
27 \\
30 \\
32 \\
36 \\
40\end{array}$ & $\begin{array}{l}1 \\
2 \\
2 \\
2 \\
2 \\
7 \\
1 \\
2 \\
1 \\
1 \\
2 \\
1 \\
1\end{array}$ & $\begin{array}{l}\text { Good } \\
\text { Good } \\
\text { Good } \\
\text { Good } \\
\text { Good } \\
\text { Good } \\
\text { Good } \\
1 \text { poor } \\
\text { Poor } \\
\text { Poor } \\
\text { Poor } \\
\text { Moderate } \\
\text { Moderate }\end{array}$ & 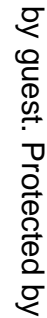 \\
\hline
\end{tabular}




\section{Results}

Cells containing antileucoprotease in the glandular and surface epithelium of the airways usually showed diffuse staining of the entire cytoplasm. The gestational age at which these cells first appeared in the various airways is shown in table 2 . Positive cells were first detected at 16 weeks in the submucosal glands of the trachea, and also in collecting ducts; in the main and lobar bronchi they were present in glands alone. At this stage only one or two positive cells were found in occasional acini and collecting ducts. By 17 weeks there were positive cells in the collecting ducts of main and lobar bronchi (fig 1), and at 20 weeks the distribution of antileucoprotease in bronchial glands was similar to that in adult tissue (fig 2). Cells

Table 2 Gestational age at which antileucoprotease was first detected in the airways of the fetal lung

\begin{tabular}{ll}
\hline & $\begin{array}{l}\text { Gestational } \\
\text { age (weeks) }\end{array}$ \\
\hline Trachea & \\
Submucosal gland & 16 \\
Collecting duct & 16 \\
Airway epithelium & 20 \\
Main and lobar bronchi & 16 \\
Submucosal gland & 17 \\
Collecting duct & 20 \\
Airway epithelium & 20 \\
Smaller bronchi & 20 \\
Submucosal gland & $20-25$ \\
Collecting duct & 36 \\
Airway epithelium & \\
Peripheral airway epithelium & \\
\hline
\end{tabular}

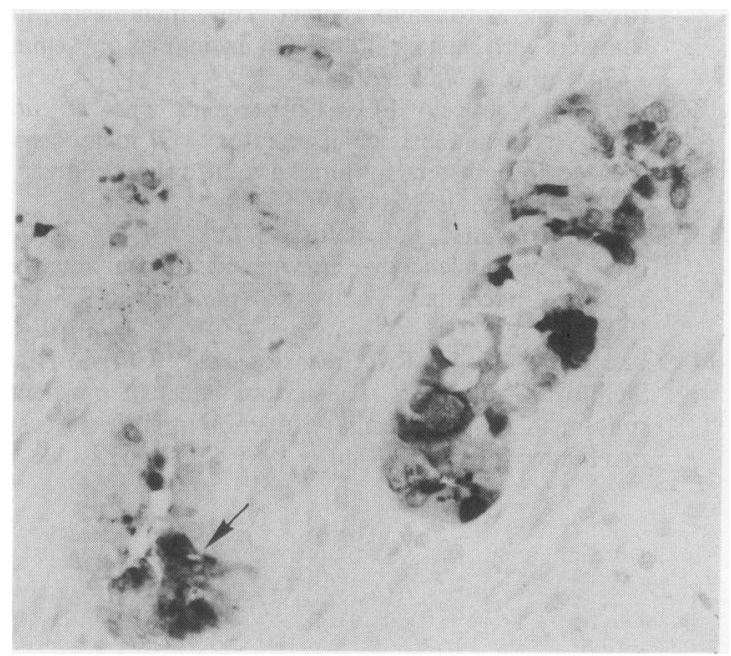

Fig 1 Main bronchus at 17 weeks, showing antileucoprotease in the cells of submucosal gland acini and a collecting duct (arrow).

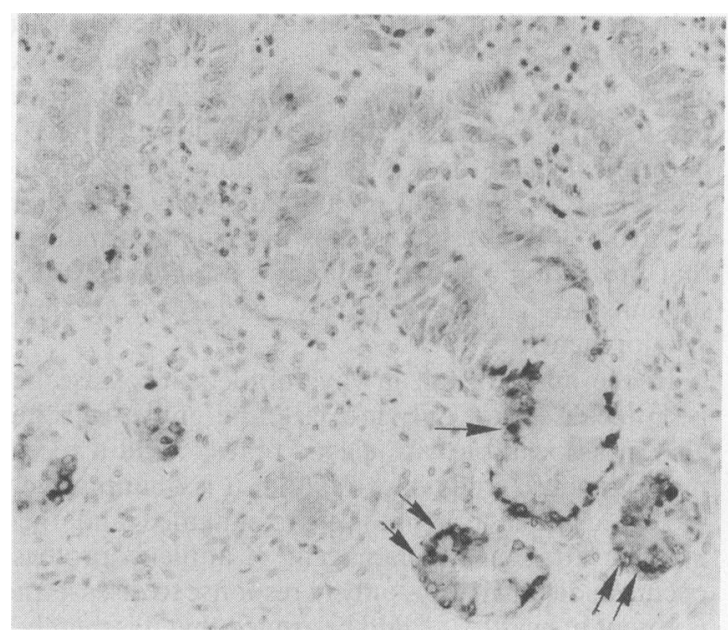

Fig 2 Large intrapulmonary bronchus at 20 weeks. The submucosal glands have matured, and only the serous cells (double arrows) contain antileucoprotease. The epithelium of the collecting duct (single arrow) region also contains antileucoprotease positive cells.

containing antileucoprotease appeared in the surface epithelium of the trachea and main and lobar bronchi at the 20th week, but could be detected in bronchiolar epithelium only in specimens of 36 and 40 weeks' gestational age.

\section{Discussion}

So far as we know this is the first report on the distribution of antileucoprotease during lung development. Our results indicate that in the human fetal lung antileucoprotease containing cells first appear centrally, and then gradually extend to the periphery, in parallel with the centrifugal pattern of airway differentiation. ${ }^{78}$ Furthermore, these cells differentiate in the surface epithelium of the trachea and larger bronchi three to four weeks later than in glandular tissue.

Antileucoprotease was not observed in bronchiolar epithelium earlier than the 36th gestational week. In adult bronchioles it has previously been shown to occur in Clara cells and goblet cells. ${ }^{2}$ Goblet cells are normally sparse in human bronchioles, occurring in appreciable numbers only after irritation and infection. They are therefore unlikely to be present in the fetus, and none was found in our material by the periodic acid-Schiff technique. Consequently it is possible that the antileucoprotease containing cells observed in the bronchioles at 36 and 40 weeks' gestation were Clara cells. This is of interest, as data on the differentiation of Clara cells during human lung development are lacking. In rabbits differentiation of these elements occurs over the first four weeks after birth. ${ }^{910}$ 
In the central airways of the adult antileucoprotease is synthesised by the serous cells of submucosal glands. ${ }^{2}$ It probably protects the bronchial lining from damage by elastase, which has been shown to have a harmful effect on the airway epithelium of experimental animals 1112 as well as on human airway epithelium in vitro. ${ }^{1314}$ The results of this investigation indicate that protection against protease is established in the submucosal glands relatively early during lung development.

In the adult distal airways antileucoprotease has been localised not only in Clara and goblet cells but also in association with elastic fibres, ${ }^{25}$ and a recent morphometric study suggests that it is quantitatively increased when bronchioles are inflamed and their alveolar attachments damaged. ${ }^{6}$ If antileucoprotease occurs in distal airways only in response to disease and is absent in health, it could be argued that it is merely a non-specific component of the inflammatory response. But as it is present in normal fetal and adult bronchioles we believe that in distal airways it is an integral part of the general first line of defence, and that increased amounts are produced as soon as disease develops to minimise tissue damage by release of elastase.

In conclusion, we have established that antileucoprotease is present in the human fetal trachea as early as the 16th week, when the adult pattern of bronchial branching is completed. It extends in a centrifugal manner over the ensuing weeks and reaches the bronchiolar epithelium by the 36 th week. Together with data from earlier investigations, these findings suggest that antileucoprotease may have an early and important role in lung defence in man. In addition, they suggest that the Clara cell develops within the last one or two months of human intrauterine life. This latter aspect requires confirmation at the ultrastructural level.

We wish to thank Mrs $G$ van Leeuwen-Herberts for her technical assistance, and Mrs E A van der Kwast for typing the manuscript.

\section{References}

1 Mooren HWD, Kramps JA, Franken C, Meijer CJLM, Dijkman JH. Localisation of a low molecular weight bronchial protease inhibitor in the peripheral human lung. Thorax 1983;38:180-3.

2 Water de R, Willems LNA, van Muijen GNP, et al. $\frac{\bar{\sigma}}{\bar{\sigma}}$ Ultrastructural localization of bronchial antileuko- $\overline{\frac{\omega}{\sigma}}$ protease in central and peripheral human airways by $a \stackrel{\Phi}{\Phi}$ gold-labeling technique using monoclonal antibodies. Am Rev Respir Dis 1986;133:882-90.

3 Kramps JA, Franken C, Meijer CJLM, Dijkman JH. $\vec{\circ}$ Localization of low molecular weight protease inhibitor in serous secretory cells of the respiratory $\vec{\omega}$ tract. J Histochem Cytochem 1981;29:712-9.

4 Willems LNA, Kramps JA, de Water R, et al. Evaluation $\overrightarrow{\times}$ of antileukoprotease in surgical lung specimens. Europ J Respir Dis 1986;69:242-7.

5 Willems LNA, Otto-Verberne CJM, Kramps JA, ten $\vec{\circ}$ Have-Opbroek AAW, Dijkman JH. Detection of $ळ$ antileukoprotease in connective tissue of the lung. Histochemistry 1986;86:165-8.

6 Willems LNA, Kramps JA, Weening JJ, Stijnen Th, Dijkman JH. Association of antileukoprotease with morphologic disease of peripheral airways [abstract]. $\frac{\stackrel{+}{0}}{0}$ Am Rev Respir Dis 1987;135:A290.

7 Reid LM. The embryology of the lung. In: de Revck AVS, Porker $\mathrm{R}$, eds. CIBA Foundation symposium on $\overrightarrow{0}$ development of the lung. London: Churchill, $1967 . \quad \infty$

8 Boyden EA. Development and growth of the airways. In: Hodson WA, ed. Development of the lung. Vol 6. Lung응 biology in health and disease. New York: Dekker, 1977.

9 Plopper CG, Alley JL, Serabjit-Singh CJ, Philpot RM. Cytodifferentiation of the nonciliated bronchiolaro epithelial (Clara) cell during rabbit lung maturation: I. $\stackrel{\mathbb{Q}}{\varrho}$ An ultrastructural and morphometric study. $\mathrm{Am} J \overrightarrow{\mathrm{F}}$ Anat 1983;167:329-57.

10 Hyde DM, Plopper CG, Kass Ph H, Alley JL. Estimation $\stackrel{3}{\supset}$ of cell numbers and volumes of bronchiolar epithelium during rabbit lung maturation. Am $J$ Anat 1983;167:359-70.

11 Christensen TG, Korthy AL, Snider GL, Hayes JA. 음 Irreversible bronchial goblet cell metaplasia in $\times$ hamsters with elastase-induced panacinar emphysema. J Clin Invest 1977;59:397-404.

12 Snider GL, Lucey EC, Christensen Th, et al.ळ Emphysema and bronchial secretory cell metaplasia 3 induced in hamsters by human neutrophil products.윽 Am Rev Respir Dis 1984;129:155-60.

13 Tegner H, Ohlsson K, Toremalm NG, Mecklenburg von C:D Effect of human leucocyte enzymes on tracheal mucosa and its mucociliary activity. Rhinology 1978;17: N 199-206.

14 Sykes DA, Wilson R, Greenstone M, Currie DC, 으 Steinfort C, Cole PY. Deleterious effect of purulentw sputum sol on human ciliary function in vitro: at least two factors identified. Thorax 1987;42:256-61. 